\title{
The Employers' Perspective of the Impact of RICS Education Reform on Building Surveying
}

\author{
Mike Hoxley $^{1}$ and Sara Wilkinson ${ }^{2}$ \\ ${ }^{1}$ Property Management and Development, School of Architecture, Design and the Built \\ Environment, Nottingham Trent University, Burton Street, Nottingham NG1 4BU, UK, \\ Tel. 0115848 4690, Email: mike.hoxley@ntu.ac.uk \\ ${ }^{2}$ Faculty of Architecture, Building and Planning, University of Melbourne, Melbourne, \\ 3010 Victoria, Australia
}

Purpose: This paper presents the second part of research funded by the RICS Education Trust to investigate the impact of the 2001 education reforms on Building Surveying. The first part of the research involved the collection of data from university course leaders

Methodology: This research involved the collection of data from large national, mainly London based, employers of building surveyors at a focus group meeting.

Findings: Issues of concern to these employers include the extent of construction technology knowledge of graduates, the delivery of contract administration, the placement year, post-graduate conversion courses and the high referral rate for the Assessment of Professional Competence (APC). Recommendations include advice to Universities on the design of building surveying undergraduate and conversion courses, a call for further research on the high APC referral rate, and greater liaison between industry and universities.

Practical implications: Both parts of this RICS Education Trust funded research provides a foundation for the Building Surveying Faculty of the RICS to complete their review of the education and training of building surveyors.

Value of paper: The main limitation of the research is that the employers from whom data were collected were mainly large, national firms. Further research would be required to elicit the views of smaller regional organisations.

Paper type: Research paper

Keywords: building surveying, conversion courses, curriculum, education, employers, training, universities.

\section{Introduction}

In 2001 the RICS introduced threshold criteria for the quality of teaching, research, graduate employment and entry qualifications of surveying courses that they accredit. The last of these criteria, led initially, to a decline in student numbers on Building Surveying courses. The RICS Education Trust awarded the researchers funding to conduct a survey of Building Surveying Course Leaders (see Wilkinson and Hoxley, $2005 \mathrm{a}$ and 2005b). Following the completion of this first study, the Education Trust awarded the researchers additional funding to canvass the views of Building Surveying (BS) Employers on the impact of the 2001 RICS Education Reforms on the profession and its future. Simultaneously one of the researchers (Hoxley) was co-opted onto the Building Surveying Faculty Board to contribute to a review of BS education and training. 
The objectives of the research were to investigate the main issues identified in the earlier study and by the early stages of the current research:

1. Concerns have been raised as to whether there is sufficient BS 'core' content in building surveying undergraduate and conversion courses.

2. There have been significant changes in the provision of surveying education in recent years so that overall there are as many surveying students studying on postgraduate conversion courses as there are on traditional undergraduate courses. While the provision of conversion courses in BS is not as advanced as other areas of surveying (e.g. General Practice) such courses are becoming increasingly important in BS. Some employers have little knowledge of conversion courses.

3. Currently, only $25 \%$ of students enrolling on RICS partnership courses in BS go on to become Chartered Surveyors (Mair, 2005, p6).

4. The pass rate (of approximately $50 \%$ ) for the BS Route to the APC is significantly lower than for most other routes.

5. In an era of booming property and construction activity, recruitment to University BS courses is growing at a slower rate than other surveying disciplines (see Figure 1).

\section{Data Collection}

With the assistance of the Building Surveying Faculty a focus group representing mainly national or London based practices (including staff engaged almost exclusively in recruitment) was convened at RICS HQ on $6^{\text {th }}$ October 2005. This focus group (of 13 employers) provided the main vehicle for data collection, although in addition, there were lengthy discussions on education issues at Faculty Board meetings in April 2005 and November 2005 that Hoxley attended. The main issues considered at the focus group meeting (referred to throughout this paper as the 'forum') and at the Faculty Board meetings are discussed below.

\section{Content of Building Surveying Courses}

Although there has been new legislation since 1997 that has impacted upon the work of Building Surveyors (e.g. the Disability Discrimination Act) the generic areas of practice and competence identified by Professor Mole (Mole, 1997) still remain valid today. In the absence of any other advice from the RICS, Universities should continue to use the 'Mind the Gap' document as the basis for BS course design.

There is a strongly held view by employers that the construction technology content of courses has shrunk over the years. This subject is at the core of the BS's competence and employers are concerned that graduates lack sufficient knowledge and understanding of basic construction technology. In the under-funded UK Higher Education sector there is increased pressure to maintain high staff/student ratios and to increase module sizes (from for example 10 and 20 credit modules to 15 and 30 credit modules). Both of these pressures can impact upon the amount of technology that is taught but employers are concerned that such pressures should be resisted. 
The teaching of contract administration to building surveying students was discussed at some length by employers. Several felt that students should be taught about the standard forms of contract that BSs use in practice (the Minor Works and Intermediate Forms) while others believed that the principles could be learnt using the Standard JCT Form provided students were made aware of the differences between this contract and the Minor Works and Intermediate Forms.

There is a firm belief amongst employers that the sandwich year in traditional undergraduate degrees is to be encouraged and most are willing to take placement students. Employers at the forum had mixed views about part-time education (some said that releasing a student for one day a week had too large an impact on their business) but all agreed that it is essential that students be taught by Chartered Building Surveyors.

There was a genuine interest expressed by all employers present to engage more with universities, but some expressed concern that universities seem non-receptive to approaches from industry. It was suggested that there was perhaps a role for the Faculty to play in encouraging more liaison between industry and education providers.

\section{Post-graduate Conversion Courses}

Conversion courses may take the form of true post-graduate degree courses or of Graduate Diploma courses that deliver under-graduate material to graduates - similar to the legal graduate conversion courses - the Common Professional Exam or Graduate Diploma in Law. Whatever the format, the RICS require Universities to structure conversion courses to have a minimum of 180 credits with a minimum of 100 credits at Level 3, i.e. final year modules. Inevitably this requirement restricts the amount of basic construction technology that can be taught. Such material is usually delivered at Level 1 of undergraduate courses and the conversion courses concentrate on Levels 2 and 3.

There were a few employers at the forum who had not yet seen any graduates from such courses (such BS courses have not been in existence as long as similar GP courses) but those that had were very positive about the quality of graduates. They were generally more mature and able to learn quickly and while it was acknowledged that the level of technical knowledge was probably less than that possessed by a graduate of an undergraduate degree, employers believed that conversion course graduates could pick up this knowledge in the work-place. It was suggested that these graduates would probably take, on average, an extra year to complete the APC (three years rather than two).

Some participants believed that the conversion course route was the one that should be encouraged as it attracted students of a higher calibre.

\section{Training - The Assessment of Professional Competence}

Delegates believed that in general the standard looked for by Assessment of Professional Competence (APC) Panels was about right. However disquiet was expressed about the higher referral rate (typically 50\%) than for other APC routes. Those employers who were also APC assessors believed that candidates are often not ready after two years of training. Those employers who employed both BS and GP 
surveyors said that 'the bar was definitely set higher for the BS route'. There was a general view that this was because of the more technical nature of building surveying.

One question asked by an employer at the forum was if we know why the BS APC route has such a high referral rate. The answer to this question appears to be 'no' and research should be conducted by analysing APC referral reports to see why candidates are being referred. This work is required urgently since there is an institutional wide review of the APC under way at the present time. The results of the recommended research should feed into this review.

Professor Trevor Mole made an interesting suggestion at the November 2005 faculty Board Meeting that instead of looking for more competencies at level 3, we should instead expect more to level 2. This would reflect the fact that building surveying is a broad based profession and that candidates should be able to demonstrate a broad competency of the core areas and more specialised competency in one or two. This suggestion has much to commend it and we encourage the Faculty to give serious consideration to it in their current review of the APC.

The alternative, which seems to be unpalatable to both employers and the Faculty Board, is to allow candidates to specialise in say either general professional matters (to include building pathology) or contract administration. The danger with this proposal is that it will dilute what the profession and its clients currently expect from building surveyors.

In his first draft of the APC Competency Review presented to the Faculty Board on $17^{\text {th }}$ November 2005 William Mair makes the disturbing observation that RICS figures suggest that currently only about one in four students commencing University courses in building surveying goes on to qualify as a Chartered Surveyor (Mair, 2005, p6). The employers attending the education forum were all from the larger firms but they made the point that small firms are at a distinct disadvantage in being able to prepare candidates for the APC. In addition the researchers have both taught excellent students who have expressed a distinct lack of interest in commencing the APC. Some of these are located in small firms but others are based in Housing Associations or Local Authorities. In the early days of the TPC and APC the type of organisation in which the candidate was based presented no such impediment to commencing a training programme leading to the APC. Indeed working for organisations such as local authorities was seen as ideal training. Of course the outsourcing of many of the property and construction functions of such organisations has led to some reduction in opportunities to train in these organisations. In any forthcoming reform of the APC the opportunity should be taken to redress the balance so that it is remains possible for candidates in small practices, housing associations and local authorities (where after all the majority of building surveyors work) to train and qualify. Key to any successful reform of the APC will, of course be the re-training of assessors.

\section{Recruitment to BS Courses}

Figure 1 below (RICS, 2005) shows recruitment to UK accredited/partnership courses from 1992 to 2004 for the subject areas of Construction, Building Surveying, Land and Real Estate. It will be seen that since the education reforms in 2001/2002 numbers on courses have risen steeply, largely as a result of the increase in numbers on conversion courses (undergraduate course recruitment has remained fairly static during this period). It will be noted however that the increased recruitment to BS courses is flatter than for the Real Estate and Construction surveying disciplines. Of 
course in construction booms where more new build is taking place than refurbishment there is bound to be more demand for some other professions, such as construction managers and quantity surveyors, than for building surveyors. Never-the-less it will be of concern to the Faculty Board that recruitment to University BS courses is lagging behind that of competitor professions.

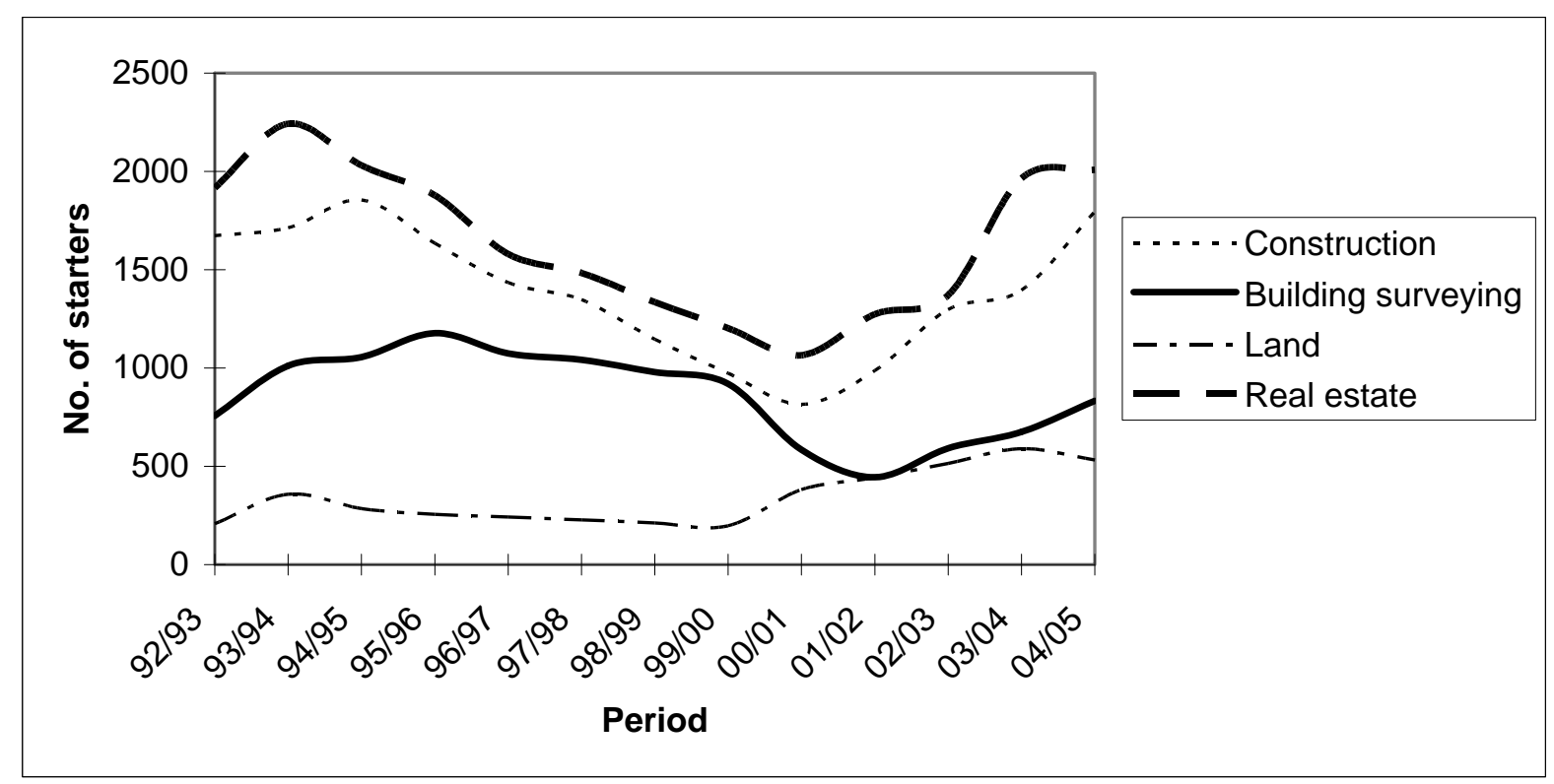

Figure 1: Starters on UK Accredited Courses (RICS, 2005)

At the Employers' Forum it was acknowledged that the high APC referral rate and the fact that it is common for candidates to require in excess of the minimum two years of professional training would be a real disincentive to school leavers and others to join the profession, were these facts to become common knowledge. One of the reasons that school leavers choose a building surveying degree rather than to study architecture is because of the shorter period of study and training. If this time differential was to continue to be eroded by failure to reform the APC, then it would further impact upon BS recruitment.

\section{Main Findings}

The large building surveying employers from whom the researchers have collected data had the following views:

1. Employers are concerned about the level of construction technology knowledge of graduates and would like to see more technology taught on building surveying programmes.

2. In teaching contract administration to building surveyors, relevant contracts should be used (principally minor works and intermediate forms).

3. Employers welcome the sandwich year on undergraduate courses and most are willing to provide placement opportunities. 
4. Employers welcome the innovation of BS post-graduate conversion courses and are generally impressed by the quality of graduates from such courses.

5. The curriculum for BS conversion courses universities should not ignore the importance of basic construction technology.

6. Employers believe the level of the BS APC route to be about right but are concerned about the high referral rate and the low take up of the APC by BS graduates.

\section{Conclusions}

The objectives of the research were to investigate the main issues identified in the earlier study (Wilkinson and Hoxley, 2005a and 2005b) and this report concludes that:

- Concerns exist regarding the adequacy of provision of BS 'core' content, for example construction technology and contract administration, in building surveying undergraduate and conversion courses. There are arguments for and against the different modes of delivery i.e. part time, full time and sandwich and the conclusion is that there remains a place for all modes in the market.

- With respect to the post-graduate conversion courses BS is not as advanced as other areas of surveying (e.g. General Practice) though such courses are becoming increasingly important in BS. The employers were generally aware of the courses though not all had direct experience of working with these graduates. Thus these recruits are largely still an unknown quantity, however the post graduate conversion recruits are perceived in a positive light as being fast learners and mature entrants to the profession. It is anticipated that completion of the BS APC may take these students longer than undergraduates.

- Currently, only $25 \%$ of students enrolling on RICS partnership courses in BS go on to become Chartered Surveyors (Mair, 2005, p6). This is a major concern to the BS profession with impediments for candidates identified as being the type or size of employer. If the trend continues the future strength of the BS profession may be weakened and numbers may wane as retirees are not replaced and growth diminishes.

- The pass rate (of approximately 50\%) for the BS Route to the APC is significantly lower than for most other routes and work is required to achieve consistency of standards across all Faculties to attain a pass at APC.

- Recruitment to University BS courses is growing at a slower rate than other surveying disciplines (see Figure 1) and this is a concern to employers. This may be attributed to the fact that many BS came through the trades or technician routes to chartered status a pathway which is now restricted by the 2001 RICS education reforms. Building Surveying expanded quickly during the latter part of the $20^{\text {th }}$ century in the UK, there is now evidence to suggest that expansion is slowing to a level where there is some concern over the longer term future of the profession given the age profile of the BS Faculty. 
RICS reforms are of course, only one side of the coin. Those in the education sector and especially the vocational education sector, have to balance the needs and aspirations of the professions they represent and also the needs of the education policymakers, and University management teams as they position their institutions nationally and internationally. This research has demonstrated that the 2001 RICS reforms have changed the way in which UK Building Surveying education is delivered. These changes are summarised as: higher entry qualifications and reduced numbers of students enrolled on undergraduate accredited building surveying courses.

\section{Recommendations}

Following this canvassing of building surveying employers' views the researchers make the following recommendations:

1. Universities should continue to use Mole (1997) as the basis of their curriculum design for BS courses.

2. The BS Faculty Board should promote and facilitate more liaison between industry and universities.

3. As a high priority the Faculty should commission or arrange for research to be undertaken into the reasons for the high referral rate in the BS route to the APC and the implications for the BS profession.

4. Consideration should be given to requiring BS APC candidates to achieve more competencies to level 2 and less to level 3.

5. In any review of the APC care should be taken to ensure that it is still possible for candidates working in small firms, local authorities, housing associations and similar organisations to succeed.

\section{References}

Mair, W, 2005, Built Environment Group, APC Competency Review, Building Surveying Faculty, First Draft, November 2005, RICS, London.

Mole, T, 1997, Mind the Gap, Report on the Rationale and Expectation of the Building Surveyors Division in the Education and Training of Chartered Surveyors, RICS, London.

RICS, 2005, Appendix 10 of Directors Report, RICS, London.

Wilkinson, S and Hoxley, M, 2005a, "The impact of the 2001 RICS education reforms on building surveying" in the proceedings of the Queensland University of Technology Research Week International Conference, Brisbane, Australia, 4-8 July 2005, pp 1222-1233.

Wilkinson, S and Hoxley, M, 2005b, "The impact of RICS education reform on building surveying" in Structural Survey, Volume 23, Issue 5, December 2005, pp 359-370. 